Tomasz Sawczuk

10.15290/cr.2016.15.4.06

University of Białystok

\title{
"I've been crawling up so long on your stairway to heaven": The rise of the female rock memoir
}

\begin{abstract}
Similarly to rock music, the rock memoir has long been considered a male genre by both the general public and publishers. It might well be claimed that throughout the years there have been many seminal female rock performers, yet only a few of them gained well deserved recognition and engaged the minds of wider audiences. The history of rock had been predominantly a (his)story until 2012 and the publication of Patti Smith's Just Kids, a female rock memoir which paved the way for many other women thus far silenced by the male-oriented genre. This paper seeks to delve into some of the female rock narratives in order to analyze the ways in which their authors construct their stories and their authorial selves. It also points to those territories of the music industry and the rock memoir which female performers strive to enrich or reclaim by the acts of writing and performing.
\end{abstract}

Keywords: female rock memoir, feminism, life writing, performance, popular culture.

With over a dozen books released in the last few years and a number of titles awaiting publication, the female rock memoir has become the latest craze in the Anglophone publishing market, frequently outnumbering the print runs of its male counterpart. A considerable part of the success of the genre and the glory of the "trailblazer" has been credited to Patti Smith and her 2010 National Book Award-winning Just Kids, an autobiographical account of the artist's life with the photographer Robert Mapplethorpe. As agreed by commentators, the rock memoir has allowed female rock artists to claim their place in the male-dominated history of rock music. A male-oriented literary genre itself, it has also opened up for the thus far marginalized experience of the feminine.

The present paper sets out to explore the storytelling and the construction(s) of the literary self in female rock memoirs. By doing so, it will demonstrate how female rock artists reconfigure the male-dominated rock memoir by touching upon the topics of independence and womanhood against the backdrop of the "man's world" of show-business. Additionally, it ventures into performance studies and the category of the liminoid to offer a better understanding of female em- 
powerment gained by performing live. Given the diversity of authors representative of the genre, the study will be confined to three recently published books, which are Kim Gordon's Girl in a Band: A Memoir (2015), Carrie Brownstein's Hunger Makes Me a Modern Girl: A Memoir (2015), and Brix Smith Start's The Rise, the Fall, and the Rise (2016). All three, written by seminal figures active in the last decades of the twentieth century, attest to the importance of enriching the genre with a female perspective.

In Chapter 9 of her memoir, Carrie Brownstein, the guitar player and singer of the American all-female rock band Sleater-Kinney, writes:

There is the identity you have in a band or as an artist when you exist for no one other than yourself, or for your co-conspirators, your co-collaborators. When you own the sounds and when who you are is whoever you want to be. There are no definitions as prescribed by outsiders, strangers; you feel capricious, full of contradictions, and areas of yourself feel frayed or blurred... But once your sound exits that room, it is no longer just yours - it belongs to everyone who hears it. And who you are is at the mercy of the audience's opinions and imagination. If you haven't spent any time deliberately and intentionally shaping your narrative, if you're unprepared, like I was, then one will be written for you. ("Mediated")

The importance of reclaiming one's artistic self and immunizing it to the projections of the male and the medial other appears to have guided not only Brownstein's project, but also many other female artists who decided to write and publish their memoirs. If, as suggested by Benie Bruner Colvin, the memoir is about constructing values (114), then, in the most general view, the female rock memoir is to deconstruct the values which were enforced on the female performers to be further able to erect a truer image of women entwined in show-business. While the rationale behind writing their own stories differs, female artists, one might infer, are bonded against being "frequently relegated to the footnotes of official rock history and the male canon" (O’Brien, 27).

Speaking in terms of narrative patterns, the scrutinized texts do not necessarily try to evade resemblance to a typical rock star memoir. They follow a general plot common to many male artist accounts, what David R. Shumway calls "the trauma and recovery story" (69), which is sometimes evident from the title of the work (as in the case of Brix Smith Start and her book entitled The Rise, The Fall, and the Rise). Shaping oneself as "a success and as a survivor" (Shumway, 69), as done, for instance, by James Brown in his memoirs, gets manifested in various ways depending on the catalyst moment in the author's life. For the discussed female memoirists such an episode comes with either leaving the band or disbanding due to health problems and family commitments (Brownstein), or due to learning about the infidelities of their husbands who also happen to be band members (Smith Start and Gordon). Also, the analyzed works fall well under what is defined by G. Thomas Couser as "a coming-of-age narrative," and, what is crucial for the further part of the study, "a conversion narrative," in which the author epitomizes "a convert ... [who] defines him- or herself in opposition to some earlier self" (9). Additionally, all of the scrutinized memoirs concur on the level of sub-narratives typical for a rock memoir. We thus encounter stories about finding 
musical inspirations, acquiring the skills of musicianship, song-writing and recording processes, band rifts, the hardships of touring, drug trips and break-ups; one also comes across elucidating song lyrics and demythologizing famous people. However, divergent from those of male rock memoirs, the language and the narrative of female rock memoirs tend to display high levels of self-reflexivity and awareness with respect to the authorial self-creation in the text. Brownstein's parlance emerges as if directly taken from the poststructuralist idiom, which in the famous words of Derrida, has made it certain that "there is nothing outside the text" ("il n'ya pas de hors-texte") since everything, including our identities, is a cultural construct mediated by language. Brownstein repeatedly summons her literary selves with respect to the textual character of one's identity just as when she begins Chapter 1 of her memoir:

This is the story of the ways I created a territory, something more than just an archipelago of identities, something that could steady me, somewhere that I belonged. ("The Sound of Where You Are")

On hearing for the first time Bikini Kill, an American punk rock band associated with the Riot grrrl movement, she reveals:

Here was a narrative that I could place myself inside, that I could share with other people to help explain how I felt... Bikini Kill's music really gave a form, a home, and a physicality to my teenage turmoil. ("Born Naked")

With a similar attentiveness to the narrative patterns governing life writing, Kim Gordon, in the introductory chapter of her book, perversely entitled "The End", undermines the very sense of writing the memoir, when she characterizes its core issue, the break-up with her husband in the following way: "[W] hat had happened was probably the most conventional story ever" ("The End").

The alertness to the ways of rendering femininity in popular culture, as well as the special emphasis which is put by the female rock memoirists on the textual character of their identity should come as no surprise. As aptly observed by Elaine Showalter, the female author has had to

find her self-in-the-world $\ldots$ by facing (affronting?) and mounting an enormous struggle with the cultural fictions-myths, narratives, iconographies, languages-which heretofore have delimited the representation of women. And which are culturally and physically saturating. (Showalter, quoted in McCue)

Female rock memoirists appear to have been triply muted and stigmatized - as female authors, as those who undertake work in the male-dominated genre of the (rock) memoir, and, finally, as female rock musicians; in his essay on gender in popular music, Keith Negus points to a number of studies which give evidence to marginalizing the female in the music scene throughout the twentieth century, be it jazz, pop or rock (154). Hence, if " $[\mathrm{t}]$ he female-authored memoir provides a broader perspective into the lives of contemporary women-the experiences of whom have his- 
torically been silenced or Othered" (McCue), then life writing offered by female rock musicians extends the scope of the insight by reclaiming the place of the female in the male-dominated fields of rock music and rock memoir. Additionally, as regards deciding on the right literary genre to thwart the misappropriation of women in show business and to regain their image, what better choice to make than to pick one which has perhaps had the most profound impact on the shape of modern culture. As pointed out by Ben Yagoda,

[m]emoir has become the central form of the culture: not only the way stories are told, but the way arguments are put forth, products and properties marketed, ideas floated, acts justified, reputations constructed or salvaged. (Yagoda, quoted in Couser, 8)

Unlike with most accounts of male rock stars, the main thrust of the discussed female rock memoirs is their way to empowerment, often self-questioned and still in the making. A special place in the process is allotted to the act of writing. Apart from Brownstein's stance, somewhat reminiscent of Helene Cixous's call for a female writership, both Gordon and Smith Start seem to emphasize its importance, and they call for taking one's narrative in one's own hands. Encouraged by a an American visual artist and a friend, Dan Graham, Gordon, a respected visual artist in her own right, began writing on art and music for REALLIFE Magazine, which paved her the way into the New York art milieux of the 1980s. As she recalls,

I got a lot of positive feedback and felt suddenly as though I had an identity in the downtown community. That essay topic unlocked the next thirty years of my life... [W] hatever doubts I had about pursuing a career in art commingled to create a forward wave of momentum, noise, and motion. It was also my way of rebelling -writing about men when it would be more natural to write about women. It was a conscious faux-intellectual premise I could indulge in, and a nod to the work that Dan, my mentor, was doing. ("Chapter 16")

Brix Smith Start gives the image of how co-authorship could change the image of a woman who recently joined the band: "When people saw that I was actually a writer, and that I was credited, they began to come around. I was no longer perceived as a hanger-on or groupie" ("1983"). Thus, what is shared by the analyzed authors is their conviction of the act of writing as something founding for one's sense of meaningfulness in the discourse, or simply, for one's sense of existence in it. Such a stance is corroborated by modern-day academia and its claims "that selves (or subjects) are always in the process of being constructed; that identity is a function of performative traits, ... and that life narrative produces a new subject" (Couser, 182). The writing subjects' heightened awareness of how empowering a tool the text may be transits the female rock memoir onto a higher level of quality. Couser continues: "at its best, life writing does not register preexisting selfhood, but rather somehow creates it. This inverts the intuitive idea that one lives one's life, then simply writes it down" (14), and such an "approach can be seen, not as denying the life in life 
writing, but as empowering life writers - and life writing" (182-183). Concluding, if "genres of life writing are sometimes defined by what they do - the work of memoir" (Courser, 14), then female rock memoirs perform two significant functions as regards empowerment. They offer female rock artists a sense of textual stability while simultaneously calling for female authorship and participation (Courser suggests that memoirs are a "particularly interactive medium" (14)).

Another contribution to independence and sense of value comes for all three memoirists with the act of performing live. Underscoring how groundbreaking and confidence-building her first performance with a punk rock band at the age of 17 was, Lucy O'Brien, a journalist writing on women in music, states: "[B]eing in a girl band at that age should be a national requirement" (16). Brownstein recalls that her first performances, child's antics, were a matter of gaining visibility and communicating successfully:

My other form of validation was through performance. Performing gave me something to do in a given moment in a room. It was a heightened way of relating to people; I could act out feelings instead of dealing with them. ("Chapter 2")

As for Brixton Smith Start, a formative experience came with a job as a live window display. The artist recalls:

I began mentally to separate the insecure teenager I was in real life and replace it with an entirely new person on stage. On stage I felt free and empowered. Old Laura was gone. I stepped up, stood in my light, and let it rip. It felt good." ("My first proper job")

We also find an analogous shift in the self in Gordon's ruminations on her first and later shows:

When I first began playing onstage, I was pretty self-conscious. I was just trying to hold my own with the bass guitar, hoping the strings wouldn't snap, that the audience would have a good experience... When I'm at my most focused onstage, I feel a sense of space with edges around it, a glow of self-confident, joyful sexiness. ("21")

Venturing into the field of performance studies, it might be observed that female rock memoirs address issues relating to the assumptions of liminoidality. A derivative of liminality, thus all nameable and indispensable rites of passage in a given community, liminoidality refers to their artistic and leisure counterparts, which might strive for similar goals. Coined by Victor Turner, the liminoid, as suggested by Jacek Wachowski, characterizes all kinds of performances and connotes finding oneself in a marginal state of being (Wachowski, 181-182). ${ }^{21}$ Taking up the risk, the performer

21 All translations here and henceforth are by the author of the article. 
finds her/himself separated from and exposed to the audience so as to experience a conversion, after which she/he unites with the community. Kim Gordon's memoir carries a similar image:

For me performing has a lot to do with being fearless. I wrote an article for Artforum in the mid-eighties that had a line in it ... quoted a lot: "People pay money to see others believe in themselves." Meaning, the higher the chance you can fall down in public, the more value the culture places on what you do. Unlike, say, a writer or a painter, when you're onstage you can't hide from other people, or from yourself either. ("The End")

As recorded by female memoirists, over the course of time and owing to performing, their vulnerability and anxiety were transformed into strengths. Brownstein notes:

Sleater-Kinney was my rescue and salvation. It was the first time I felt I could be vulnerable in my creativity in which the emotional and psychic stakes were neither futile nor self-annihilating. ("Chapter 21")

Smith Start speaks of her acting classes: "Acting class was teaching me more than acting. It was teaching me how to love myself, and how perceived weaknesses could actually turn to strengths" ("Earthquake"). Although she speaks of it as an act of "cleansing" ("The End"), Gordon approaches performing differently since, unlike Brownstein and Smith Start, she relies on her artistic personas as comfort zones:

[T]he page, the gallery, and the stage became the only places my emotions could be expressed and acted out comfortably. These were the venues where I could exhibit sexuality, anger, a lack of concern for what people thought. The image a lot of people have of me as detached, impassive, or remote is a persona that comes from years of being teased for every feeling I ever expressed. When I was young, there was never any space for me to get attention of my own that wasn't negative. Art, and the practice of making art, was the only space that was mine alone, where I could be anyone and do anything, where just by using my head and my hands I could cry, or laugh, or get pissed off. (" 6 ")

As observed by Wachowski, the marginal phase of the liminoid is "some kind of a critical point, the state of intensified activity and creativity" (180), which "entails moving from one frame of mind to an entirely different one" (180). The discussed female rock narratives resemble a procession of such moments, putting emphasis on the fluid nature of both artistic and real-life identities and therefore making another original contribution to the genre of rock memoir. Brownstein writes:

[P]erforming was no longer about trying to harness a cursory attention or to be a distraction. SleaterKinney allowed me to perform both away from and into myself, to leave and to return, forget and discover. Within the world of the band there was a me and a not me, a fluctuation of selves that I could reinvent along the flight between perches. I could, at last, let go ... . ("Chapter 21") 
Reinvention is also the key word in the lexicon of Smith Start's memoir since it links the breaking points of her experience as a TV show host, an actress, a musician, and a businesswoman. "Every performance," Wachowski continues, "always has to disturb the already-established state of balance" (263). The authenticity and value in both life and art emerge, as the discussed memoirists would say, not with yielding to categorizing and complacency but with a hunger for uncertainty and challenge, which is another feature distinctive to female rock narratives. Of entitlement, so common in the world of art and music, Brownstein writes:

[It] is a precarious place from which to create or perform -it projects the idea that you have nothing to prove, nothing to claim, nothing to show but self-satisfaction, a smug boredom. It breeds ambivalence. It's as if instead of having to prove they are something, these musicians prove they aren't anything. It's an inverted dynamic, one that sets performers up to fail, but also gives them a false sense of having already arrived. I don't understand how someone would not push, challenge ... . ("Chapter 17")

Such tactics seem to find their way into the creation of the female memoir. Brownstein writes: "I learned later on how hard it can become to unsettle yourself, to trip yourself up, and I think that's a good place to write from. It's important to undermine yourself and create a level of difficulty so the work doesn't come too easily" (“Chapter 7"). Rather than delve nostalgically and safely into the past, the discussed memoirs prefer to set out as a challenge to the present. In this respect, Brownstein continuously unbalances and reworks her authorial self. Writing about her father's homosexuality, she realizes the need to retroactively revalue parts of herself which were already categorized: "I have to turn over and reimagine certain moments from my childhood and make them conform to a different narrative, a different outcome ("No Normal"). Similarly, Brix Smith Start's book emerges as a painful readjustment of neglected and traumatic events. In the acknowledgments to her memoir she admits:

\footnotetext{
Being so honest in public was/is scary. Being so honest with myself has been life-changing. Writing this book unearthed many buried feelings and experiences, which rose like noxious gases through the layers of my subconscious. I was forced to look at these unpleasant and uncomfortable aspects of myself in the harsh light of day, and make peace with them. ("Acknowledgements")
}

Similarly, Kim Gordon's edifice occasionally crumbles under the self-interrogatory mode of her memoir as she ponders over taking more risk: "Back then, and even now, I wonder: Am I "empowered"? If you have to hide your hypersensitivity, are you really a "strong woman"?" (“Confusion"). Thus, the scrutinized female writing subjects seem not to find completion in the text of the memoir, nor do they perceive past events as carrying permanently fixed meanings. They instead wish to see themselves in a perennial state of in-betweenness, which they embrace as a form of resistance against appropriation and self-complacency. Such authorial strategies echo Nancy Chodorow's views on the female as characterized with a fluid sense of self: 
[G]rowing girls come to define and experience themselves as continuous with others; their experience of self contains more flexible and permeable ego boundaries. Boys come to define themselves as more separate and distinct, with a greater sense of rigid ego boundaries and differentiation. (169)

It is interesting to see how the discussed memoirists engage the metaphor of girlhood to add some further impetus to the concept of in-betweenness. Jacqueline Warwick and Allison Adrian point out that

Carrie Brownstein of Sleater-Kinney titled her memoir Hunger Makes Me a Modern Girl at age 41, while Kim Gordon, whose musical career did not even begin until she co-founded the band Sonic Youth at the age of 28 , called her memoir Girl in a Band. (4)

While, on the one hand, the present-day "discourse is indicative of the expansion of girlhood into what was once considered adulthood" (Warwick and Adrian, 4), on the other hand, assuming the identity of a girl makes a perfect vessel for the female performers' sense of creative hunger and the always-becoming of their selves.

Extrapolating Chodorow's ideas to the field of life writing, the narrative rendition of the female is also frequently considered to be a multiple, contradictory and linguistically inconsistent creation. Such is the stance of the Personal Narratives Group and their seminal examination of female narratives entitled Interpreting Women's Lives: Feminist Theory and Personal Narratives (1989), in which the stylistic diversity and heterodoxy of female accounts is to be underscored, embraced and preserved: “[W]omen's personal narratives are essential primary documents for feminist research... They can take many forms, including biography, autobiography, life history - a life story told to a second person who records it - diaries, journals, and letters" (4). Embracing various faces of in-betweenness, female rock memoirs appear to modify the conversion subgenre they represent - the writing female subject is no longer a one-time convert yet a perpetual one, which defines itself not in opposition to a single previous self, but to previous selves.

Finally, the scrutinized memoirs serve as a pungent commentary on the misappropriations of the female-in-a-band image. They allocate numerous pages to settling with the confined number of behavioural patterns expected of women in popular culture. A line from Sleater-Kinney's song entitled “\#1 Must Have” reads: "I've been crawling up so long on your stairway to heaven" (2010) and, as reflected in the discussed memoirs, it holds for much of the struggle a woman goes through to be acknowledged as an artist in her own right. The space has already been taken. As suggested by Brownstein, "[t]he archetypes, the stage moves, the representations of rebellion and debauchery were all male" ("Chapter 8"), as in the case of a male loner figure. The male loner, Brownstein continues, "is a hero of sorts, a rebel, an iconoclast, but the same is not true of a female loner. There is no virility in a woman's autonomy, there is only pity" ("Chapter 20"). Kim Gordon corroborates the image: 
In general ... women aren't really allowed to be kick-ass. It's like the famous distinction between art and craft: Art, and wildness, and pushing against the edges, is a male thing. Craft, and control, and polish, is for women. Culturally we don't allow women to be as free as they would like, because that is frightening. We either shun those women or deem them crazy. ("21")

Clear gender distinctions also hold for the choice of the instrument and the music genre. Keith Negus points to a number of studies devoted to female rock musicianship. All of them "demonstrate how children and young adults, along with their teachers, parents and carers, have been grappling with enduring historical legacies whereby certain instruments and performance styles are deemed more appropriate for boys and girls" (154). He moreover points to sentiments of the community fiercely defending rock as "phallo-centric music" and the rock voice as "almost definitely masculine" (155). Not toeing the line, as the discussed memoirs demonstrate, ends up with commodification and misappropriation of various sorts. Upon going through Sleater-Kinney's first big feature in Spin magazine, Brownstein reflects

[I]t was the first time I felt like I was reading about someone I didn't know. The writer characterized me as a burbling groupie of Corin's, casting me as obsequious and frivolous. I wasn't reading about myself; I was reading about a character the writer had made up to fit his tendentious point of view about the band, a narrative he was creating that we needed to fit inside. ("Mediated")

For Gordon, the ultimate level of commodifying the female in show-biz comes with The Spice Girls, a group put together by men, each Spice Girl branded with a different personality, polished and stylized to be made marketable as a faux female type. ("21")

Both she and Brownstein identify in their memoirs the quintessential role that a woman gets in the culture, and more specifically, in the world of entertainment:

The role of a woman onstage is often indistinct from her role offstage-pleasing, appeasing, striking some balance between larger-than-life and iconic with approachable, likable, and down-to-earth, the fans like gaping mouths, hungry for more of you. (Brownstein, "Chapter 12")

The discussed authors' experience informs criticism devoted to the expectations of the music industry and its male decision makers in regards to the image of the female. Andi Zeisler explains the role of the male gaze in shaping certain assumptions functioning in show business:

In a world ordered by sexual imbalance, pleasure in looking has been split between active/male and passive/female. The determining male gaze projects its fantasy onto the female figure, which is styled 
accordingly... It makes sense that many girls and women grow up seeing images of girls and women the way men do-the images themselves are simply constructed that way. ... Seeing the visual cues of the male gaze, in turn, affects how women understand images of other women. (quoted in McCue)

Not being able to pigeonhole a female artist as either an accessory to the show or an attractive creature comfort, the media exert all of their power to make her explain herself. Brownstein draws a broad image of the problem:

This is where we were starting to grapple with something we would grapple with for the rest of our time as a band: that there was always a sense we were going to have to defend and analyze what we were doing. Why are you in an all-female band? Why do you not have a bass player? What does it feel like to be a woman in a band? ["What's it like to be a mom in rock?" ("35"), Gordon adds in her memoir] I realized that those questions - that talking about the experience-had become part of the experience itself. More than anything, I feel that this meta-discourse, talking about the talk, is part of how it feels to be a "woman in music" (or a "woman in anything," for that matter-politics, business, comedy, power). There is the music itself, and then there is the ongoing dialogue about how it feels... To this day, because I know no other way of being or feeling, I don't know what it's like to be a woman in a band-I have nothing else to compare it to. But I will say that I doubt in the history of rock journalism and writing any man has been asked, "Why are you in an all-male band?" ("Chapter 8")

"I've been crawling up so long on your stairway to Heaven" Sleater-Kinney sings in "\#1 Must Have," and it adds straightaway: "And now I no longer believe that I wanna get in" (2010). To conclude, speaking of the female experience from the heart of the male-dominated discourse of rock music and the rock memoir, the discussed female rock narratives achieve a number of goals. In the most general sense they enrich the well-established type of narrative with the thus far marginalized accounts of the female rock artists and ensure their rightful place in the history of rock music. In the spirit of Nancy K. Miller and her calls for deconstructing the alleged maleness of the literary canon, they advocate a gendered rereading of the rock memoir narrative. Since "memoir is ... the narration of our own lives in our own terms" (Couser, 9), the life writing of female rock musicians reclaims space for personal freedom to construct one's identity and challenges various gendered misconceptions regarding the image and place of women in the entertainment industry, as well as in modern-day society. It is both a proof of female empowerment (even if not ultimate) and a call for female empowerment, which, as all three works demonstrate, might come with the acts of performing and/by writing. Finally, in line with the bulk of feminist criticism and against the prevailing trends in rock memoir writing, the discussed memoirists espouse textual fluidity, contradictoriness and in-betweenness of their writing selves, which, on the one hand, allows them and their public images to evade being locked within a fixed set of categories, and on the other, enables them to remain truly active and ambitious in the sphere of art. 


\section{References}

Brownstein, Carrie. 2015. Hunger Makes Me a Modern Girl: A Memoir [ebook]. New York: Riverhead Books.

Chodorow, Nancy. 1978. The Reproduction of Mothering: Psychoanalysis and the Sociology of Gender. Berkeley and Los Angeles: University of California Press.

Colvin, Benie Bruner. 2008. Passing the Story: A Study of Personal Memoirs - Letters, Recipes, and Quilts. Doctoral dissertation. Indiana, PA: Indiana University of Pennsylvania.

Couser, G. Thomas. 2012. Memoir: An Introduction. New York: Oxford University Press.

Gordon, Kim. 2015. Girl in a Band: A Memoir [ebook]. New York: HarperCollins Publishers.

McCue, Jennifer Anne. 2014. "Empowering the Female Voice: Interdisciplinarity, Feminism, and the Memoir." Journal of Integrated Studies 5.1. 10 Jun. 2017. http://jis.athabascau.ca/index. php/jis/article/view/140/152

O’Brien, Lucy. 2016. "I'm With the Band: Redefining Young Feminism." Voicing Girlhood in Popular Music: Performance, Authority, Authenticity. Ed. Jacqueline Warwick and Allison Adrian. New York: Routledge, 15-36.

Negus, Keith. 2017. “The Gendered Narratives of Nobodies and Somebodies in the Popular Music Economy." The Routledge Research Companion to Popular Music and Gender. Ed. Stan Hawkins. New York: Routledge, 152-165.

Personal Narratives Group, ed. 1989. Interpreting Women's Lives: Feminist Theory and Personal Narratives. Bloomington: Indiana University Press.

Shumway, David R. 2014. Rock Stars: The Making of Musical Icons from Elvis to Springsteen. Baltimore: John Hopkins University Press.

Sleater-Kinney. 2010. “\#1 Must Have.” Portland: Kill Rock Stars.

Start, Brix Smith. 2016. The Rise, the Fall, and the Rise [ebook]. London: Faber \& Faber.

Wachowski, Jacek. 2011. Performans. Gdańsk: słowo/obraz terytoria.

Warwick, Jacqueline and Allison Adrian. 2016. "Introduction.” Voicing Girlhood in Popular Music: Performance, Authority, Authenticity. Ed. Jacqueline Warwick and Allison Adrian. New York: Routledge, 1-11. 